\title{
Planning for Integrative Management of Wastewater Disposal, Irrigation Water Supply and Fertilizer Use: A Case Study in an Arid Land of China
}

\author{
Guangwei Huang \\ Graduate School of Global Environmental Studies, Sophia University, Tokyo, Japan \\ Email: huang@genv.sophia.ac.jp
}

How to cite this paper: Huang, G.W. (2017) Planning for Integrative Management of Wastewater Disposal, Irrigation Water Supply and Fertilizer Use: A Case Study in an Arid Land of China. Journal of Water Resource and Protection, 9, 482-492. https://doi.org/10.4236/jwarp.2017.95031

Received: March 6, 2017

Accepted: April 25, 2017

Published: April 28, 2017

Copyright () 2017 by authors and Scientific Research Publishing Inc. This work is licensed under the Creative Commons Attribution International License (CC BY 4.0).

http://creativecommons.org/licenses/by/4.0/

\begin{abstract}
This work is a trans-disciplinary undertaking aiming at innovative water management in arid and semi-arid regions. Based on field studies on soil bacterial communities and irrigation water quality in an arid region of China where wastewater has been used for agricultural production decade long, this paper is intended to propose an integrative management scheme combining wastewater reuse in agriculture, wise use of wetlands and fertilizer management as an engine toward achieving sustainable development in arid and semi-arid regions. This study was also designed to address a key but very much neglected question about wastewater reuse in irrigation: does wastewater irrigation lead to reduction of chemical fertilizer use and increase of crop yield? Through a questionnaire, it revealed that there was a misperception among farmers about wastewater, which led to no-reduction or even increase in fertilizer use with wastewater irrigation as compared with river water irrigation. It also showed that crop yield was not increased with wastewater irrigation under the current practice. Besides, it sheds some light on an underreported health concern.
\end{abstract}

\section{Keywords}

Arid Regions, Wastewater Irrigation, Fertilize Use, Crop Yield, Soil Bacterial

\section{Introduction}

Arid lands may be simply defined as regions where evaporation exceeds precipitation. Three arid zones can be delineated according to this definition: namely, hyper-arid, arid and semi-arid. Of the total land area of the world, the hyper- 
arid zone covers 4.2 percent, the arid zone 14.6 percent, and the semiarid zone 12.2 percent. Therefore, almost one-third of the total area of the world is arid land. In spite of water scarcity, there is a long history of agricultural development in arid regions across the world. In China, arid and semi-arid regions occupy a vast land in north-western China accounting for one-quarter of the Chinese territory in which agriculture has flourished under such a climate. For example, in Xinjiang Uygur Autonomous Region, $3.93 \times 10^{6}$ ha of farmlands were created from 1950 to 1998. In the dry Minqin county in the lower reaches of the Shiyang River, cultivated land increased by an area of $27.5 \times 10^{3}$ ha between 1987 and 2001. The output of grain production in Gansu Province, where the annual precipitation was less than $300 \mathrm{~mm}$, increased by more than $40 \%$ during the period of 2003-2012.

Meanwhile, arid and semi-arid regions are urbanizing at a fast pace. The rate of urbanization in Africa soared from 15\% in 1960 to $40 \%$ in 2010, and is projected to reach $60 \%$ in 2050. In Gansu Province, Shaanxi Province and Xinjiang Autonomous Region, the average rate of urbanization increased from $24 \%$ to $38.8 \%, 32.2 \%$ to $50 \%$ and $34 \%$ to $47 \%$ during the period of $2000-2012$, respectively. Arid zones are now home to over 2 billion people, accounting for $35 \%$ of the world's population. Besides, more than $90 \%$ of dryland inhabitants are in the developing world and $70 \%$ in rural areas. Approximately half of the poorest people in the world live in arid and semi-arid regions. Because of low economic growth, urban wastewater collection and treatment systems are often lagging behind the rapid increase of urban population in arid and semi-arid regions. As a result, large amount of urban wastewater is directly discharged into natural water bodies without any treatment causing further increase of water scarcity by water pollution.

To feed the world's anticipated nine billion people by 2050, agriculture development in arid and semi-arid regions must be continued due to the availability of land, light, and heat resources in arid and semi-arid regions and low availability of new productive land in wet regions.

Another serious concern emerged during the past several decades in agricultural sector, especially in developing countries, is the overuse of chemical fertilizers. Due to limited water availability and low soil fertility in arid and semi-arid regions, crop responses to inputs as fertilizers are generally slow so that farmers tend to apply more fertilizer to sustain crop yields. The notion of more fertilizer consumption in arid and semi-arid regions can also be supported by studies in the 1960s and 1970s, which indicated that irrigated crops overwhelmingly dominated fertilizer consumption and agriculture in arid regions is largely irrigated farming [1] [2]. It has also been well documented that fertilizer overuse may contaminate groundwater and cause health problems [3].

Meanwhile, wastewater reuse in agriculture is gaining more importance and more acceptances due to increasing water scarcity in water scarce regions of both the developed and developing worlds. It was estimated that globally, 7 per cent of the total irrigated land in the world are indeed irrigated by wastewater [4]. It was also projected that 80 percent of wastewater in developing countries 
may be used for irrigation [5] and untreated wastewater is used to irrigate at least 500,000 hectares in Latin America [6]. In China, wastewater reuse in agriculture has been practiced for over 50 years, and more than 3.3 million ha of the arable land is currently irrigated with domestic or industrial wastewater. Given that water scarcity and drought events are likely to be more severe and more frequent in the future due to climate change and increasing population, the potential role of wastewater reuse as an alternative source of water supply is now well acknowledged and adopted as international and national strategies for dealing with the increase of water stress across the planet. UN Sustainable Development Goal on Water (SDG 6) specifically targets a substantial increase in recycling and safe reuse globally by 2030. In addition to serving as an alternative water resource, wastewater reuse can provide significant environmental, social and economic benefits by relieving pressure of wastewater discharge into natural waterways, supplying poor farmers with needed nutrients for crops and needed organic matter for soil.

There have been substantial researches on wastewater irrigation ranging from public health risks [7], guidelines [8], effects on physicochemical properties of soil [9], farmer's willingness to use wastewater [10], treatment technology [11] to nutrients availability [12]. These studies have greatly advanced our understanding upon public health risk and environmental impacts of wastewater reuse. However, the emphasis has so far been placed on regulation, standards, guidelines of effluent to reduce public health risk and change of physico-chemical properties of the soil due to wastewater application. The responses of soil microbes to wastewater irrigation have been much neglected according to the study of Becerra-Castro [13]. Besides, little attention has been paid to how wastewater reuse in irrigation could be managed to contribute to the reduction of fertilizer. Although wastewater may meet $75 \%$ of the fertilizer requirements [14], do farmers really reduce fertilizer use when using wastewater remains largely unexplored and how wastewater irrigation affects crop yield is also poorly understood. Previous studies [15] [16] indicated that domestic wastewater irrigation could improve plant yields and soil fertility. These results, however, were obtained from controlled experiments. The actual field performance of wastewater irrigation in terms of crop yield remains unclarified.

In view of the aforementioned issues, the present study was designed to address the problems of water shortage, urban wastewater disposal, wastewater reuse in agriculture and over-fertilizer in one bucket. An initiative was taken linking these issues together in an innovative way by wise management of wetlands. The purpose is to explore answers to the following research questions.

- How long-term wastewater irrigation may affect soil bacterial community?

- Does wastewater irrigation lead to reduction of chemical fertilizer use? If not, why?

- Does wastewater irrigation increase crop yield?

- What are ways forward to improve the current situations with regard to water shortage and wastewater reuse for irrigation?

Through probing into these questions, a framework is proposed for solving a 
number of problems simultaneously. Although it is a case study, the concept and the framework can be considered as having a wide range of applicability.

\section{Study Site and Methods}

\subsection{Site Description}

The present study was conducted in Zhangye City, Gansu Province, China. The city is located in the middle reaches of Heihe River, which is the second largest inland river in China. The target region is characterized by a dry continental climate, with mean annual precipitation less than $200 \mathrm{~mm}$ and annual potential evaporation of $2000 \mathrm{~mm}$ or more. The renewable water resource per capita in Zhangye City is $1250 \mathrm{~m}^{3} / \mathrm{yr}$, just $5 \%$ of the world average. Despite of its water scarcity, large-scale agriculture has been developed over the past decades. Due to its natural conditions, the farming in this region is only possible via irrigation, which led to an excessive consumption of water [17]. Under such a condition, a technical solution for sustainable agriculture in the Zhangye basin is wastewater reuse, which can provide not just another source of irrigation water but a source of plant nutrients. According to our field survey, wastewater reuse for irrigation has been put into practice for more than a decade in certain areas of the Zhangye basin. The amount of wastewater generated in the urbanized areas of the Zhangye City is $0.19 \times 10^{7} \mathrm{~m}^{3}$ and about $30 \%$ of it is currently reused in agriculture.

This region is also characterized by its abundant wetlands with reeds Phragmites as being dominant. Over the past several decades, the wetlands in this region have become seriously degraded due to agricultural development, population growth, effluent discharge from households and industries, and overexploitation of groundwater. In the 1990s, 1300 ha of wetland were reclaimed for farming. The study by Wang and Ma [18] showed that the total area of wetlands in this region decreased sharply during the period of 2007-2007 due mainly to the implementation of surface water diversion to the lower reaches of the Heihe River that reduced water availability in the middle reaches of the Heihe River. Consequently, wetlands conservation competes with the demand for irrigation water. In the past, most of the city's wastewater was discharged into wetlands without treatment degrading the wetlands to a serious extent. In recent years, the local government prohibited the discharge of wastewater into wetlands according to an interview with the Environmental Protection Bureau of the Zhangye City. For wastewater reuse in agriculture, channels were constructed to transport wastewater to farmlands. The present study was particularly focused on a channel along the Donghuan Road which transports certain amount of urban wastewater after simple treatment by septic tank to farmlands in the Sanzha town. The agricultural production in the Sanzha town is composed of 112 farmer's cooperatives and a number of farmer's cooperatives in the area receive urban wastewater from this wastewater channel and use it for irrigation. A portion of the wastewater transporting channel in the downtown area is adjacent to a reed wetland and designed to bypass the wetland as shown in Figure 1. 


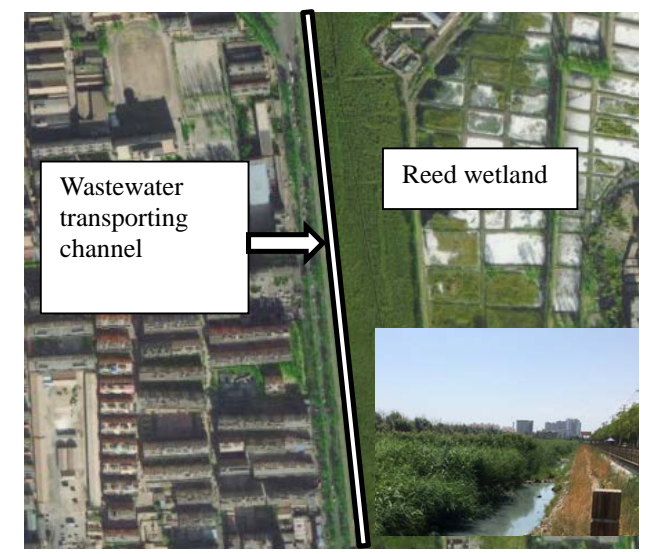

Figure 1. A channel transporting wastewater from downtown to farmlands.

\subsection{Methods}

Water quality measurements were conducted along the wastewater channel from the downtown to the point where the wastewater flows into farmlands in July 2015, June 2016 and August 2016. Meanwhile, three fields cultivating maize but using different types of irrigation water, namely river water, groundwater and wastewater, were investigated for soil bacterial community. 8 soil samples were taken from the surface layer of $10 \mathrm{~cm}$ at each site in July 2015. In addition, soil $\mathrm{pH}$, temperature and nitrate concentration of the surface layer and the water quality of wastewater entering the fields were measured. The information for the three sites is compiled in Table 1.

To investigate the composition of soil bacterial communities, DNA was extracted from soil with Norgen's Soil DNA Isolation Kit and 16S rRNA gene sequencing approach with the V3-V4 regions being amplified was employed for characterizing bacterial populations. For details of the soil survey, readers are referred to [19]. Sequencing data were analyzed with standard Quantitative Insights Into Microbial Ecology (QIIME) software package.

In August 2016, a farmer-interview was conducted with a semi-structured questionnaire in 10 farmer's cooperatives where wastewater has been used for irrigating maize for a decade. The sampling approach is a combination of homogeneous sampling in choosing farmer's cooperatives and convenience sampling in choosing farmers in each farmer's cooperative. In each farmer's cooperative, 2 to 6 households were interviewed. In this region, most of the farmers are engaged in other income-generating activities in addition to their farming activities. Many houses were closed so that it was very difficult if not impossible to get access to many farmers to keep the sample size large and uniform at all the locations. The questionnaire included questions to identify the interviewee's age, education level, type of irrigation water used, fertilizer use, crop yield and what they are concerned most about wastewater irrigation. In total, 41 farmers were interviewed. They are aged between 20 years and 60 years having the literacy level varied from illiterate to middle school with the majority belonged to the illiterate group. The names of farmer's cooperatives surveyed and the number of farmers interviewed are summarized in Table 2. 
Table 1. Soil sampling site and soil temperature, pH in July 2015.

\begin{tabular}{ccccc}
\hline Irrigation water type & Latitude & Longitude & Soil Tem. $\left({ }^{\circ} \mathrm{C}\right)$ & Soil pH \\
\hline River water & $38^{\circ} 53^{\prime} 14.4^{\prime \prime}$ & $100^{\circ} 20^{\prime} 05^{\prime \prime}$ & 25 & 7.0 \\
Wastewater & $39^{\circ} 00^{\prime} 16.7^{\prime \prime}$ & $100^{\circ} 30^{\prime} 44.4^{\prime \prime}$ & 23 & 7.0 \\
Groundwater & $39^{\circ} 00^{\prime} 15.6^{\prime \prime}$ & $100^{\circ} 30^{\prime} 41^{\prime \prime}$ & 25 & 7.0 \\
\hline
\end{tabular}

Table 2. Survey site and number of farmers interviewed in each site.

\begin{tabular}{cccccc}
\hline Cooperative name & $\begin{array}{c}\text { Tianqiao } \\
\text { Unit } 1\end{array}$ & $\begin{array}{c}\text { Tianqiao } \\
\text { Unit 2 }\end{array}$ & $\begin{array}{c}\text { Tianqiao } \\
\text { Unit } 9\end{array}$ & $\begin{array}{c}\text { Gaozhao } \\
\text { Unit 3 }\end{array}$ & $\begin{array}{c}\text { Gaozhao } \\
\text { Unit } 6\end{array}$ \\
\hline Number of interviewee & 5 & 2 & 2 & 3 & 2 \\
Cooperative name & $\begin{array}{c}\text { Gaozhao } \\
\text { Unit } 8\end{array}$ & $\begin{array}{c}\text { Gaozhao } \\
\text { Unit } 9\end{array}$ & $\begin{array}{c}\text { Wayao } \\
\text { Unit 3 }\end{array}$ & $\begin{array}{c}\text { Wayao } \\
\text { Unit 4 }\end{array}$ & $\begin{array}{c}\text { Genming } \\
\text { Unit 7 }\end{array}$ \\
Number of interviewee & 6 & 2 & 2 & 7 & 2 \\
\hline
\end{tabular}

\section{Results and Discussions}

\subsection{Soil Bacterial and Water Quality}

Figure 2 shows the OTUs (Operational Taxonomic Unit, clustered at a 97\% similarity) abundance levels and soil nitrate contents of the three sites measured in June 2016. Species richness in the wastewater irrigated field is lower than the river water irrigated field but close to the groundwater-fed field. Previous studies [20] [21] showed that relative abundance and diversity of soil bacteria were related to $\mathrm{pH}$ since $\mathrm{pH}$ may strongly influence both abiotic and biotic factors of soil. The present study presents a case in which the relative abundance and diversity of soil bacteria varied from site to site while having the same $\mathrm{pH}$ value. In other words, the difference in soil bacteria abundance may be deemed as a result of the difference in irrigation water.

Water quality testing showed that the concentration of ammonium $\mathrm{NH}_{4}-\mathrm{N}$ in the wastewater entering into farmlands ranged between 18 to $22 \mathrm{mg} / \mathrm{L}$ and the concentration of nitrate $\mathrm{NO}_{3}-\mathrm{N}$ varied from 12 to $19 \mathrm{mg} / \mathrm{L}$ in all measurements. According to the study of [22], excessive nitrogen addition to soil may result in lower soil bacterial diversity. The concentrations of $\mathrm{NH}_{4}-\mathrm{N}$ and $\mathrm{NO}_{3}-\mathrm{N}$ in the river water for irrigation were measured to be in the range of $0.5-1 \mathrm{mg} / \mathrm{L}$ and 5 - $8 \mathrm{mg} / \mathrm{L}$, respectively, during the surveys. Therefore, the relatively low level of soil bacterial species richness in the wastewater irrigated field may be attributed to excessive nitrogen addition by the wastewater.

On the other hand, the soil nitrate level in the wastewater irrigated field was also lower than the river water irrigated field at the time when the cultivation in 2016 just started. To explain why the soil nitrate level in the wastewater irrigated field was lower than the river water irrigated field, denitrifying bacteria was examined. Paracoccusdenitrificans was not detected but Pseudomonas was found present in the three fields. The relative abundance is $0.43 \%$ for the wastewater irrigated site and $0.1 \%$ for the river water irrigated site. This finding could be supported by the study of Friedel [9], which demonstrated that soil denitrifying 


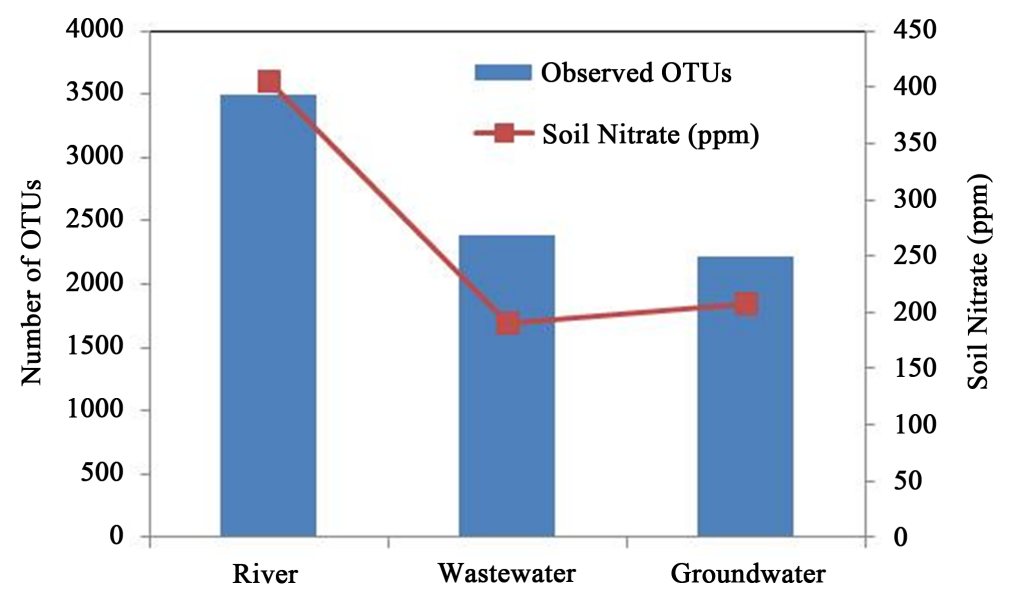

Figure 2. OTUs abundance levels and soil nitrate contents at different fields.

activity was stimulated with long-term wastewater irrigation as compared to those under rain-fed agriculture. Therefore, it may be stated that the current wastewater irrigation practice resulted in lower diversity overall but enhanced certain bacterium such as Pseudomonas, which led to more reduction of nitrate in the surface layer of soil as a result.

The field survey also found that although the wastewater channel is designed to bypass the reed wetland, a certain amount of wastewater flowed through the wetland. The water qualities of the water flowing in and flowing out the wetland were measured during the survey and found that the ammonium concentration of wastewater coming out the wetland was reduced approximately by $60 \%$. A previous study for the same reed wetland indicated that the removal rate of $\mathrm{NH}_{4}$ ranged between $40 \%$ to $80 \%$ [23]. These findings suggest that if wastewater is allowed to enter into the wetland with sound planning, it may output wastewater with desirable quality for irrigation.

\subsection{Social Aspects}

$80 \%$ of all interviewed replied that the amount of fertilizer applied when using wastewater for irrigation is not less than that previously used when using river water. $20 \%$ replied that they even increased fertilizer use when wastewater was used. The reason is that they have a misperception about wastewater. They took the view that wastewater is of bad quality so that fertilizer use should not be reduced and may even need to apply more fertilizer to compensate.

As for crop yield, 95\% replied no increase while 5\% said the yields were decreased indeed. There is no overlap between those who increased their fertilizer use and those who suffered from yield losses. This finding of no yield increase with wastewater irrigation may be supported by a previous study [24], which indicated that although reclaimed wastewater may produce better quality crops with high yields, excessive nitrogen in wastewater can lead to excessive vegetative growth, uneven plant and fruit maturity, and reduced qualitative and quantitative aspects of yields. Therefore, applying more nutrients when using wastewater than using river or groundwater for irrigation could have caused the ferti- 
lization exceed the optimal level and resulted in no further increase or even decline in yield. For farmers, yield is a top concern. The no-reduction or even increased use of fertilizer when using wastewater can be viewed as their defense against yield decline when information and technical support are not available. According to the present survey, $94 \%$ of farmers interviewed said that they have never received any technical guidance on nutrients in wastewater. $6 \%$ received guidance and training in fertilizer management offered by the local authority. Besides, for those interviewed, $46 \%$ never had any formal education, $34 \%$ graduated from primary school, $14 \%$ graduated from middle school and only $6 \%$ attended high school. It is just this $6 \%$ that received technical guidance and training about fertilizer use. Nevertheless, even this $6 \%$ having taken guidance and training did not reduce their fertilizer use simply because they did not want risk yield loss although they knew it could be reduced. This implies that the technical guidance delivered to farmers was insufficient and did not convince farmers. Therefore, the combination of concern about yield, high level of illiteracy, limited and insufficient technical support from administration prevented farmers from taking the benefits of nutrients availability from wastewater reuse.

When asked what concerned them most about wastewater reuse, all pointed to odor emitted from irrigation channels transporting wastewater. Every day, the bad smell was worst around dinner time according to all interviewees. Along the wastewater delivering channel, the water quality measurement at a location close to where the wastewater was diverted into farmland showed that $\mathrm{NH}_{4}-\mathrm{N}$ concentration peaked at 19:00 and was as high as $22 \mathrm{ppm}$. This measurement confirmed the farmer's complaint. In either WHO or EPA guidelines for safe wastewater reuse, the odor control guideline has not been established and there is no study so far on health effects of odor from wastewater reuse.

\subsection{Integrative Solution Framework}

In light of the problems identified and findings obtained from the field work, an integrative solution is proposed as illustrated in Figure 3. Urban wastewater may be discharged into wetlands after simple treatment, which can relieve the city from the heavy financial burden of constructing sewer system and treatment plant. By carefully planning the amount of wastewater entering the wetland and the wastewater residence time in wetland, it may simultaneously meet the demand for water by wetland and the requirement for better wastewater suited to agricultural needs. The point is not to purify wastewater to highly clean water but to reduce the nutrients level in wastewater to certain extent. Once the irrigation water contains sufficient but not excessive nutrients, the use of chemical fertilizers can be reduced, which may improve the quality of soil and groundwater water, and contribute to the reduction of $\mathrm{CO}_{2}$ emission as well. Besides, such an operation would not damage the wetland ecosystem since it does not require excessive removal of nutrients by wetlands. For the case of the Zhangye city, the amount of urban wastewater from households was $2.3 \times 10^{7} \mathrm{~m}^{3}$ in 2014 according to the statistical book of the city. The annual water demand for maintaining 


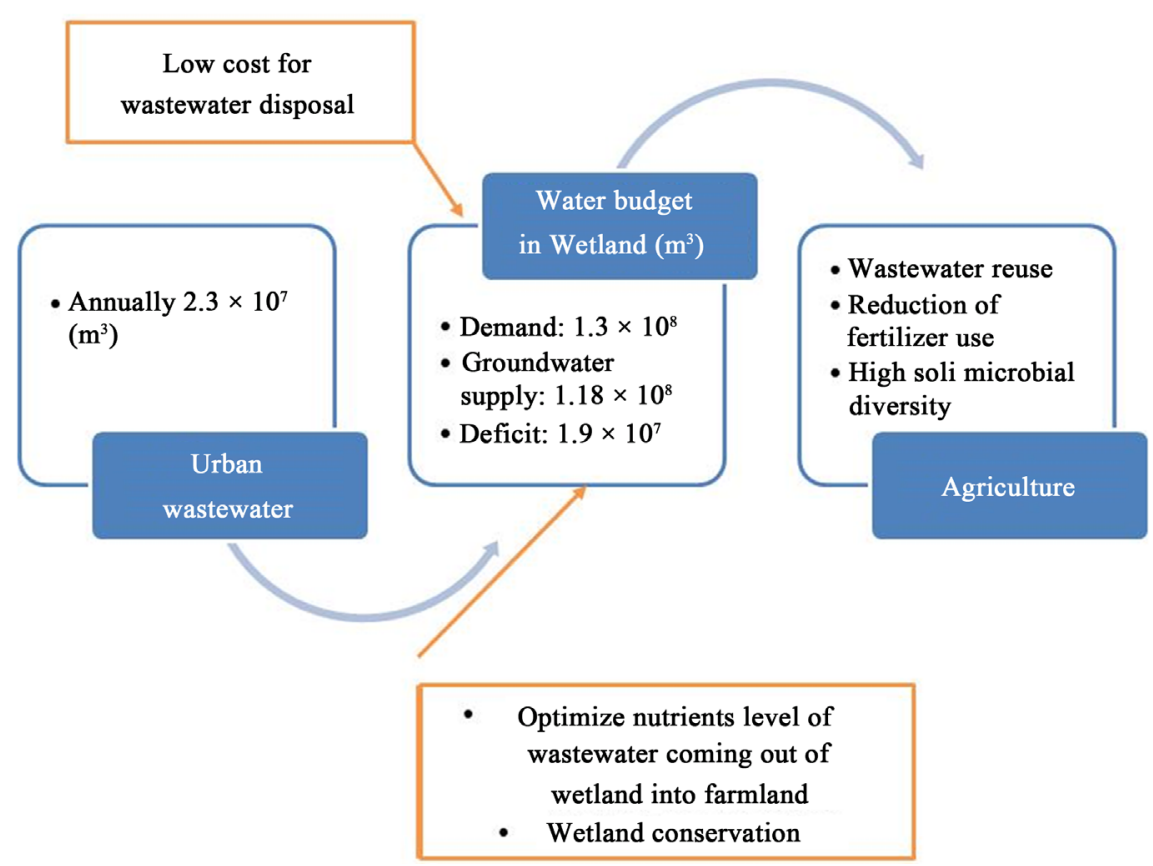

Figure 3. Framework for dealing with issues of water supply to farmlands, urban wastewater disposal and reduction of chemical fertilizer use all together through wise use of wetlands. Data in the figure is for the case study.

the ecosystem in the wetland conservation area of the Zhangye city was estimated to be $1.3 \times 10^{8} \mathrm{~m}^{3}$ and the current supply from groundwater is $1.3 \times 10^{8}$ $\mathrm{m}^{3}$. The deficit is $1.9 \times 10^{7} \mathrm{~m}^{3}$, which could be largely compensated by wastewater reuse. However, a key to make this solution workable is innovative use of wetlands to optimize the water quality of wastewater suitable for irrigation and without damaging the wetlands. Another key is to develop tailor-made education and training programs of fertilizer application for the local communities.

\section{Conclusions}

This cross-disciplinary study revealed that the current practice of wastewater irrigation in the study area did not lead to reduction of chemical fertilizer use, which might be attributable to a combination of soil bacterial and social factors. From soil science perspective, wastewater irrigation resulted in relatively lower soil bacteria abundance while enhancing soil denitrifying bacteria. Consequently, the reduced nitrate contents in soil may have caused a misperception among famers that wastewater is of bad quality, and more chemical fertilizer should be used to compensate when wastewater is used for irrigation. From social perspective, such a misperception may be related to the high level of illiteracy of farmers and low level of technical support from the local government. Furthermore, the present survey found that the wastewater irrigation did not increase crop yield in the study area, which might be attributed to over-fertilization due to excessive fertilizer input when using wastewater for irrigation.

To overcome the problems the study area is faced with, the present study proposes a solution framework of dealing with problems of water scarcity, urban 
wastewater and fertilizer overuse all together through wise use of wetlands.

This work serves as a call for more in-depth study to quantify crop yield response to fertilizers when wastewater is used for irrigation. Besides, bad smell emitted from open channel transporting wastewater was identified as a top health concern for farmers living nearby.

\section{Acknowledgements}

This work was supported by the Flagship Research Fund of Sophia University. Thanks should be given to Profs. Li Xin, Wang Jian, Che Tao, Wang Weizhen, Huang Chulin of the Chinese Academy of Sciences for their generous support to this field-based study. Assistance in the fieldwork by graduate students from Sophia University, Tokyo University of Agriculture and Technology and Chinese Academy of Sciences, especially, He Hui, Kang Ningyue, Alejandro Diaz Aragon, Kazuki Shinoda, Daisuke Taniguchi, Gao Jianqi, Lu Yi, Kim Kihoon, Pang Yaning, is deeply appreciated.

\section{References}

[1] Densai, G.M. (1969) Growth of Fertilizer Use in India Agriculture: Past Trends and Future Demand. Cornell International Agricultural Development Bulletin 18, Cornell University, Ithaca, New York.

[2] NCAER (National Council of Applied Economic Research) (1974) Fertilizer Use on Selected Crops in India. NCAER and Fertilizer Association of India.

[3] Hallberg, G.R. (1987) The Impacts of Agricultural Chemicals on Ground Water Quality. GeoJournal, 15, 283-295. https://doi.org/10.1007/BF00213456

[4] Future Harvest (2001) Wastewater Irrigation: Economic Necessity or Threat to Health and Environment? Future Harvest, Washington DC.

[5] Cooper, R.C. (1991) Public Health Concerns in Wastewater Reuse. Water Science and Technology, 24, 55-65.

[6] Moscosco, J. (1996) Aquaculture Using Treated Effluents from the San Juan Stabilization Ponds, Lima, Peru. Abstracts of Recycling Waste for Agriculture: The RuralUrban Connection, The World Bank, Washington DC, 23-24 September 1996.

[7] Fattal, B., Wax, Y., Davies, M. and Shuval, H.I. (1986) Health Risks Associated with Wastewater Irrigation: An Epidemiological Study. American Journal of Public Health, 76, 977-979. https://doi.org/10.2105/AJPH.76.8.977

[8] WHO (2006) The Third Edition of the WHO Guidelines for the Safe Use of Wastewater, Excreta and Greywater. World Health Organization.

[9] Friedel, J.K., Langer, T., Siebe, C. and Stahr, K. (2000) Effects of Long-Term Wastewater Irrigation on Soil Organic Matter, Soil Microbial Biomass and Its Activities in Central Mexico. Biology and Fertility of Soils, 31, 414-421. https://doi.org/10.1007/s003749900188

[10] Madi, A., Braadbaart, O., Al-Sa'ed, R. and Alaerts, G. (2003) Willingness of Farmers to Pay for Reclaimed Wastewater in Jordan and Tunisia. Water Science and Technology: Water Supply, 3, 115-122.

[11] Bickers, P.O. and Bhamidimarri, R. (1998) Aerobic Treatment of Reverse Osmosis Permeate in the Dairy Industry for Reuse. Water Science and Technology, 38, 6167. https://doi.org/10.1016/S0273-1223(98)00498-3 
[12] Pereira, B., He, Z., Stoffella, P. and Melfi, A. (2011) Reclaimed Wastewater: Effects on Citrus Nutrition. Agricultural Water Management, 98, 1828-1833. https://doi.org/10.1016/j.agwat.2011.06.009

[13] Becerra-Castro, C., Lopes, A.R., Vaz-Moreira, I., Silva, E.F., Manaia, C.M. and Nunes, O.C. (2015) Wastewater Reuse in Irrigation: A Microbiological Perspective on Implications in Soil Fertility and Human and Environmental Health. Environment International, 75, 117-135. https://doi.org/10.1016/j.envint.2014.11.001

[14] Carr, G., Potter, R.B. and Nortcliff, S. (2011) Water Reuse for Irrigation in Jordan: Perceptions of Water Quality among Farmers. Agricultural Water Management, 98, 847-854. https://doi.org/10.1016/j.agwat.2010.12.011

[15] Yang, B., Kong, X., Cui, B., Jin, D., Deng, Y., Zhuang, X., Zhuang, G. and Bai, Z. (2015) Impact of Rural Domestic Wastewater Irrigation on the Physicochemical and Microbiological Properties of Pakchoi and Soil. Water, 7, 1825-1839. https://doi.org/10.3390/w7051825

[16] Singh, P.K., Deshbhratar, P.B. and Ramteke, D.S. (2012) Effects of Sewage Wastewater Irrigation on Soil Properties, Crop Yield and Environment. Agricultural Water Management, 103, 100-104. https://doi.org/10.1016/j.agwat.2011.10.022

[17] Huang, G. (2015) From Water-Constrained to Water-Driven Sustainable Development-A Case of Water Policy Impact Evaluation. Sustainability, 7, 8950-8964. https://doi.org/10.3390/su7078950

[18] Wang, H. and Ma, M. (2016) Impacts of Climate Change and Anthropogenic Activities on the Ecological Restoration of Wetlands in the Arid Regions of China. Energies, 9, 166-191. https://doi.org/10.3390/en9030166

[19] Huang, G., Takahashi, S., Liu, H., Saito, T. and Kimura, N. (2016) Characterization of Soil Bacterial Diversity in Relation to Irrigation Water: A Case Study in China. Journal of Water Resource and Protection, 8, 1090-1102. https://doi.org/10.4236/jwarp.2016.812086

[20] Aciego Pietri, J.C. and Brookes, P.C. (2008) Nitrogen Mineralisation along a pH Gradient of a Silty Loam UK Soil. Soil Biology and Biochemistry, 40, 797-802. https://doi.org/10.1016/j.soilbio.2007.10.014

[21] Rousk, J., Baath, E., Brookers, P.C., Lauber, C.L., Lozupone, C., Caporaso, J.G., Knight, R. and Fierer, N. (2010) Soil Bacterial and Fungal Communities across a pH Gradient in an Arable Soil. The ISME Journal, 4, 1340-1351. https://doi.org/10.1038/ismej.2010.58

[22] Li, H., Xu, Z., Yang, S., et al. (2016) Responses of Soil Bacterial Communities to Nitrogen Deposition and Precipitation Increment Are Closely Linked with Aboveground Community Variation. Microbial Ecology, 71, 974-989. https://doi.org/10.1007/s00248-016-0730-z

[23] Zhang, J. and Liu, C. (2012) Design of Wetland Landscape along Donghuan Road in Zhangye City and Ecological Effect Analysis. Grassland and Lawn, 3, 34-48. (In Chinese)

[24] Pedrero, F., Kalavrouziotis, I., Alarcon, J.J., Koukoulakis, P. and Asano, T. (2010) Use of Treated Municipal Wastewater in Irrigated Agriculture-Review of Some Practices in Spain and Greece. Agricultural Water Management, 97, 1233-1241. https://doi.org/10.1016/j.agwat.2010.03.003 
Submit or recommend next manuscript to SCIRP and we will provide best service for you:

Accepting pre-submission inquiries through Email, Facebook, LinkedIn, Twitter, etc. A wide selection of journals (inclusive of 9 subjects, more than 200 journals)

Providing 24-hour high-quality service

User-friendly online submission system

Fair and swift peer-review system

Efficient typesetting and proofreading procedure

Display of the result of downloads and visits, as well as the number of cited articles Maximum dissemination of your research work

Submit your manuscript at: http://papersubmission.scirp.org/

Or contact jwarp@scirp.org 